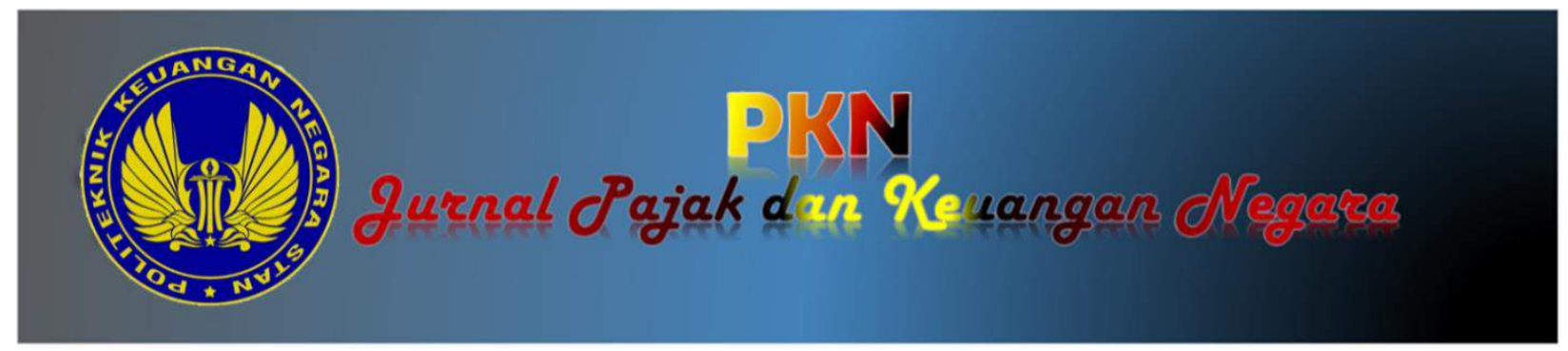

\title{
CAPITAL ASSET PRICING MODEL (CAPM) DAN ACCUMULATED / DISTRIBUTION LINE UNTUK PENENTUAN KELOMPOK SAHAM-SAHAM EFISIEN
}

\author{
Arly Turlinda \\ Fakultas Ekonomi dan Bisnis Universitas Trisakti \\ Hasnawati* \\ Fakultas Ekonomi dan Bisnis Universitas Trisakti \\ *Correspondence author: hasnawati@trisakti.ac.id
}

\author{
INFORMASI ARTIKEL \\ Diterima Pertama \\ [15 10 2020] \\ Dinyatakan Diterima \\ [31 Maret 2021] \\ KATA KUNCl: \\ CAPM, Accumulation and Distribution Line, actual return \\ saham, expected return saham.
}

KLASIFIKASI JEL: G140

\begin{abstract}
This study aims to see which groups of stocks are included in the efficient stock group using the Capital Asset Pricing Model (CAPM) and the Accumulation and Distribution Line method. The population in this study was 697 shares of companies listed on the Indonesian stock exchange during the period 2016 to 2019. The sampling method used was purposive sampling so that 109 observational data that met the criteria were obtained. To assess the efficiency of shares is done by comparing the stock actual return (Ri) with the expected return of stock $E$ (Ri). Efficient stocks have a value of Ri greater than E (Ri) or [Ri> E (Ri)], while inefficient stocks are stocks that have a value of Ri less than $E(R i)$ or [Ri <E (Ri)]. This study found that there are 54 company stocks that are included in the efficient stock category and 55 stocks which are included in the inefficient category.
\end{abstract}

Penelitian ini bertujuan untuk melihat kelompok saham yang termasuk kelompok saham efisien dengan menggunakan metode Capital Asset Pricing Model (CAPM) serta Accumulation and Distribution Line. Populasi dalam penelitian ini adalah 697 saham perusahaan yang terdaftar di bursa efek Indonesia selama periode 2016 sampai 2019. Metode sampling yang digunakan adalah purposive sampling technique sehingga didapatkan 109 data observasi yang memenuhi kriteria. Untuk menilai efisiensi saham dilakukan dengan membandingkan actual return saham (Ri) dengan expected return saham $\mathrm{E}(\mathrm{Ri})$. Saham efisien memiliki nilai Ri lebih besar daripada $E(R i)$ atau [Ri $>E(R i)]$, sedangkan saham tidak efiesien adalah saham yang memiliki nilai Ri lebih kecil daripada $E(R i)$ atau $[R i<E(R i)]$. Penelitian ini menemukan bahwa terdapat 54 saham perusahaan yang termasuk dalam kategori saham efisien dan 55 saham termasuk kategori tidak efisien. 


\section{PENDAHULUAN}

Pada saat melakukan investasi, seorang investor akan dihadapkan pada suatu pilihan untuk menentukan jenis investasi yang akan dimiliki. Dalam pengambilan keputusan terhadap jenis investasi yang dipilih, tentu saja investor akan mempertimbangkan return dan risiko yang akan timbul atas keputusan tersebut. Masing-masing investor mampu menanggung risiko yang berbeda-beda, tetapi tentu investor mengharapkan return yang sebanding dengan risiko yang diambil. Kedua faktor tersebut diperhitungkan dengan pertimbangan pengambilan keputusan karena merupakan dua faktor yang saling berhubungan. Dari hasil perhitungan terhadap ratarata return tahunan dari 3 jenis aset yang berbeda, diperoleh sebuah kesimpulan bahwa semakin besar risiko dari sebuah asset, maka semakin besar pula return yang diperoleh. Hal ini sejalan dengan salah satu prinsip keuangan yang diungkapkan bahwa "Higher returns are expected for taking on more risk". (Melicher \& Norton, 2017)

Pada prinsipnya, para investor akan menghadapi dua jenis risiko, yaitu risiko yang dapat didiversifikasi (tidak sistematis) dan tidak terdiversifikasi (sistematis). Risiko yang dapat didiversifikasi adalah komponen dari risiko aset yang dapat dihilangkan membangun portofolio yang terdiversifikasi dengan baik. Risiko sistematik dikaitkan dengan pergerakan keseluruhan di pasar umum dan disebut sebagai risiko pasar. Risiko pasar adalah komponen dari total risiko yang tidak dapat dihilangkan melalui diversifikasi portofolio. (Gitman \& Zutter, 2012).

Untuk menentukan tingkat risiko dan return yang dapat diperoleh, maka dikembangkanlah berbagai alat ukur untuk menentukan tingkat risiko beserta tingkat pengembalian yang ideal. Salah satu alat ukur yang digunakan adalah Capital Asset Pricing Model (CAPM). CAPM pada mulanya dikembangkan oleh (Sharpe, 1964) dan (Lintner, 1965). Metode ini menghubungkan return yang diharapkan dengan ukuran risiko sistematisnya. CAPM menyediakan sebuah metodologi untuk mengkuantifikasi risiko dan mentranslasi menjadi expected return on equity (ROE). Kelebihan utama CAPM adalah kemampuan untuk mengestimasi cost of equity yang bisa dihasilkan oleh sebuah model, sehingga CAPM telah menjadi alat penting untuk penilaian kinerja portofolio, diversifikasi portofolio, peniliaian investasi, dan memilih strategi portofolio. (Rossi, 2016)

Pada perhitungan CAPM, return dan risiko dinilai berdasarkan indeks tanpa mempertimbangkan volume transaksi. Padahal jika dilihat kembali, salah satu komponen penting yang perlu diperhatikan adalah volume transaksi. Volume perdagangan saham berpengaruh terhadap volatilitas harga saham karena informasi yang diterima oleh pelaku pasar berasal dari volume perdagangan saham (Dewi \& Suaryana, 2016). Effendi dan Hermanto (2017) menemukan bahwa volume perdagangan saham berhubungan positif dengan return saham, sedangkan Christiana, Septiana dan Mamduch (2016) menemukan terdapat hubungan siginifikan antara return saham dengan volume perdagangan pada situasi pasar yang positif (bullish)

Volume perdagangan di pasar saham memiliki kaitan erat dengan indikator akumulasi dan distribusi dimana indikator ini dapat membantu mengidentifikasi volume perdagangan di pasar saham.

Penelitian ini menggunakan accumulation distribution line ( $A D L$ ) sebagai salah satu tolak ukur dalam pemilihan jenis saham yang akan diamati. Hal ini disebabkan karena dengan melakukan pengamatan $A D L$, kita dapat melihat pergerakan volume. Sebagai satu alat analisis pergerakan volume, ADL akan mambantu seorang investor untuk mengamati cashflow karena metode ini pada prinsipnya menilai pergerakan volume dari suatu saham yang diperdagangkan di pasar. Pergerakan volume perdagangan saham akan selalu mendahului pergerakan harga dari saham, sehingga pengguna dapat melakukan forecasting terhadap arah pergerakan harga dan akan memperoleh gambaran mengenai harga saham kedepannya. Accumulation distribution line ( $A D L$ ) menggunakan harga saham sebagai sebuah indikator untuk mengkonfirmasi indikasi penguatan harga saham (strength) dan kestabilan dibalik trend pergerakan harga dan volume. Sehingga hal ini mampu digunakan untuk melakukan mengindentifikasi kenaikan dan penurunan volume transaksi dari sebuah saham. (Edwards, Mage, \& Bassetti, 2019)

Andriyani, Farida, Machfiroh (2016) meneliti 20 saham terpilih (dari Indeks Sri-Kehati) yang diperoleh selama 31 bulan, yaitu April 2013 hingga Oktober 2015. Hasil penelitian mengindikasikan bahwa secara signifikan terdapat perbedaaan return dan risiko portofolio antara pemilihan saham menggunakan CAPM dengan pemilihan saham menggunakan stochastic dominance. Afolabi, Njogo, Areghan, Olugbenle \& Olusesi (2017) meneliti saham bulanan dari 20 perusahaan yang terdaftar di bursa efek Nigeria dari periode Januari 2006 - Desember 2015. Periode ini meliputi periode sebelum dan sesudah terjadi krisis ekonomi global 2008/2009. Penelitian ini menggunakan teknik ordinary least square dan tidak menemukan bukti konklusif untuk penerapan model CAPM untuk saham yang tercatat pada bursa di Nigeria. Model Penetapan harga aset modal pada perusahaan sektor teknologi Indeks Nikkei 225 menunjukkan hasil yang berfluktuasi setiap tahun dan efektif dalam menentukan saham yang efisien dan tidak efisien untuk digunakan investor dalam pengambilan keputusan investasi. Harga saham perusahaan di sektor teknologi Indeks Nikkei 225 menunjukkan kenaikan rata-rata harga saham setiap tahunnya, serta model CAPM berpengaruh positif signifikan terhadap Harga Saham (Dinahastuti, 2019). 
Dari 20 perusahaan yang tergabung dalam indeks LQ45 pada tahun 2012-2016, terdapat 10 perusahaan berada pada kondisi efisien dan 10 perusahaan berada pada kondisi tidak efisien (Susanti \& Putra, 2018). Riset ini merupakan pengembangan dari riset yang dilakukan oleh Susanti dan Putra (2018). Adapun yang membedakan penelitian ini dengan penelitian Susanti dan Putra (2018) terletak pada (1) periode pengamatan yang menggunakan tahun terbaru dari tahun 2016 sampai dengan 2019; (2) pemilihan sampel. Penelitian sebelumnya memilih sampel saham yang tergabung didalam LQ45, sedangkan penelitian ini memilih sample berdasarkan hasil ADL yang memiliki arah positif; (3) penelitian ini mempertimbangkan volume transaksi sebagai variable kontrol dalam pemilihan sampel. Hal ini dilakukan karena salah satu faktor yang akan membuat investor/pasar bereaksi adalah volume perdagangan saham. (4) penelitian ini enggunakan metode weighted average dengan adanya pertimbangan periode suku bunga yang mengalami beberapa kali perubahan dalam 1 tahun.

Penelitian ini bertujuan bertujuan untuk mengetahui penggunaan CAPM untuk pemilihan saham efisien di Bursa Efek Indonesia pada periode 2016 - 2019 dengan mempertimbangkan volume transaksi atas pendagangan saham tersebut. Kontribusi penelitian ini terdiri dari kontribusi teoritis dan kontribusi praktis. Kontribusi teoritis berupa tambahan literature untuk penelitian pada ranah pasar modal, khususnya penelitian mengenai pemilahan dan pemilihan antara saham yang efisien dan yang tidak efisien. Untuk kontribusi praktis diharapkan hasil penelitian ini bermanfaat bagi investor dalam pengambilan keputusan untuk berinvestasi dengan cara memilih saham sesuai dengan selera risiko dari investor dan keuntungan yang diharapkan.

\section{KERANGKA TEORI}

\subsection{Kerangka Teori}

\subsubsection{Saham}

Saham (stock) adalah representasi hak kepemilikan pada sebuah perusahaan. Jika perusahaan hanya mengeluarkan satu kelas saham saja, saham ini disebut dengan saham biasa (common stock). Untuk menarik investor potensial lainya, suatu perusahaan mungkin juga mengeluarkan jenis saham lain dengan hak istimewa yang disebut dengan saham preferen. (Jogiyanto, 2015). Pada praktik saat ini yang dijual di Bursa Efek Indonesia adalah jenis saham biasa.

Harga saham merupakan salah satu indikator keberhasilan manajemen perusahaa atau dengan kata lain harga saham merupakan cerminan dari laba yang diraih oleh perusahaan. Laba akuntansi adalah salah satu faktor penentu harga saham (Dechow, Sloan\& Zha 2014; Kothari, 2001). Jika harga saham suatu perusahaan selalu meningkat, baik investor maupun calon investor menganggap emiten telah berhasil dalam mengelola bisnisnya dan akan meningkatkan kepercayaan investor. Hal ini akan berdampak pada jumlah permintaan saham. Semakin banyak permintaan atas saham suatu emiten, maka dapat menaikkan harga saham tersebut dan sebaliknya (Thalassinos \& Politis, 2012).

Keuntungan yang dapat dipeoleh investor di Bursa Efek dari common stock berasal dari dividend dan capital gain. Capital gain adalah selisih antara harga pasar pada saat pembelan dan penjualan kembali saham, sementara dividend adalah pembagian laba perusahaan ke pemegang saham. Pada Analisa kali ini, yang menjadi poin of return yang dibahas adalah analisa capital gain tanpa memperhitungkan dividend yang diterima oleh investor.

\subsubsection{Risk and Return}

Risiko adalah ketidakpastian mengenai imbal hasil atau pengembalian di masa yang akan datang atas investasi yang dilakukan. (Melicher \& Norton, 2017). Pendapat lain menyatakan risiko sebagai faktor yang memberikan pengaruh buruk dan harus ditangani untuk tercapainya penyelesaian pekerjaan yang dibatasi oleh waktu, biaya dan kualitas (Norken, Purbawijaya, \& Saputra, 2015). Berdasarkan pengertian tersebut dapat diambil kesimpulan bahwa risiko merupakan ketidakpastian dimasa mendatang mengenai suatu hal sebagai akibat yang timbulkan dari sebuah keputusan (Singh, Jain, \& Yadav, 2016). Return sebuah saham dapat dihitung berdasarkan harga lampau di pasar (ex post), harga aktual atau harga yang diproyeksikan (ex ante) (Marty, 2015). Merujuk pada pendapat tersebut, dapat ditarik sebuah kesimpulan bahwa bahwa return merupakan suatu presentase pengembalian yang didapatkan oleh seorang investor pada saat melakukan penyetoran modal ke suatu investasi.

Terdapat hubungan trade-off antara risiko dan expected return dalam investasi, baik itu aset (bill/bond) maupun securities (saham). Berdasarkan prinsip keuangan yang berlaku, semakin tinggi risiko yang diambil, seorang investor yang rasional akan mengharapkan return yang semakin tinggi. (Melicher \& Norton, 2017). Hal ini berarti setiap keputusan yang diambil oleh investor, tentunya akan dinilai efisien ketika actual return yang diperoleh lebih besar dari expected return. Astuty (2017) menemukan bahwa terdapat hubungan negatif antara risiko sistematis dengan harga saham LQ 45 pada periode 2011-2015. (Mazouz, Alrabadi, \& Yin, 2012) menemukan bahwa saham, dengan risiko likuiditas sistimatik yang rendah bereaksi efisien baik terhadap saham positif atau negative, sedangkan untuk saham dengan risiko likuiditas sistimatik yang tinggi kurang bereaksi. Ini berlaku untuk saham yang yang terdaftar di Financial Times Stock Echange, London. 


\subsubsection{Capital asset pricing model Capital asset pricing model (CAPM)}

Beberapa ahli memberikan definisikan mengenai CAPM. Chen (2017) mendefinisikan sebagai pengungkapan pengembalian aset sebagai fungsi risiko, yang pada gilirannya biasanya dinyatakan sebagai volatilitas atau beta. Bodie, Kane \& Marcus (2018) mendefinisikan CAPM merupakan sekumpulan prediksi mengenai keseimbangan perkiraaan imbal hasil terhadap aset berisiko. Sedangkan menurut Gitman et al (2012), CAPM adalah sebuah fungsi matematis yang yang dapat menghubungkan risiko sistematis dengan expected returns dari total asset pada portofolio investor. Berdasarkan definisi tersebut, dapat disimpulan bahwa CAPM adalah suatu rumusan yang dapat digunakan untuk menghitung estimasi pengambilan atas keputusan investasi terhadap suatu saham dengan pertimbangan risko bawaan dari suatu sekuritas.

Mulanya Capital Asset Pricing Model (CAPM) diperkenalkan oleh Sharpe, Lintner, dan Mossin pada pertengahan tahun 1960-an dan masih digunakan sampai saat ini untuk melakukan perhitungan expected return dari sebuah saham. Penggunakan CAPM ini dapat membantu para investor khsususnya untuk perhitungan return dan risk yang atas sekuritas yang dipilih. Penentuan expected return merupakan hal yang penting, karena dengan mengetahui performa dari saham tersebut, investor dapat melakukan pengaturan terhadap pilihan sekuritas juga dapat melakukan perkiraan terhadap performa dan kerugian atas portofolio yang dimiliki. Pilihan sekuritas dapat juga disesuaikan dengan profil risiko dari investor. Expected return tersebut juga dapat digunakan investor untuk melakukan aksi jual atau beli terhadap seuatu sekuritas. Misalnya untuk saham yang berada performanya diatas dari expected return, investor dapat membeli saham tersebu, sementara jika dibawah dari expected return, investor dapat menjualnya untuk menghindari kerugian yang akan muncul di kemudian hari.

Asumsi yang digunakan dalam CAPM sifat dari masa depan sama dengan masa lalu dan hanya dapat digunakan dalam kondisi perekonomian yang stabil. Asumsi-asumsi yang digunakan pada model CAPM yaitu (Marty, 2015) :

a. Investor mengevaluasi portofolio dengan melihat pengembalian yang diharapkan dan deviasi standar dari portofolio selama satu periode waktu.

b. Investor tidak pernah merasa puas, jadi ketika diberi pilihan antara dua portofolio yang identik, mereka akan memilih satu dengan ekspektasi pengembalian yang lebih tinggi.

c. Investor menghindari risiko, jadi ketika diberi pilihan antara dua portofolio yang identik, mereka akan memilih satu dengan standar deviasi yang lebih rendah. d. Aset individu dapat dibagi tanpa batas, yang berarti bahwa investor dapat membeli sebagian kecil dari saham jika dia menginginkannya. Ada tingkat bebas risiko di mana investor dapat meminjamkan atau meminjam uang.

e. Pajak dan biaya transaksi tidak relevan.

Unsur-unsur yang membentuk CAPM secara garis besar terdiri dari:

a. Beta $(\beta)$ - indicator yang digunakan untuk pengukuran tingkat risiko dari saham.

b. Risk free rate - umumnya menggunakan tingkat pengembalian dari surat berharga pemerintah.

c. Return market - diperoleh dari rata-rata tingkat pengembalian di pasar saham yang diperhitungkan.

\subsubsection{Accumulation and Distribution}

Accumulation and Distribution adalah salah satu indikator perdagangan pasar saham yang menunjukkan hubungan antara harga dengan volume transaksi dan aktivitas yang mempengaruhi perubahan harga. Indicator ini dapat melakukan identifikasi antara keadaan harga pasar saham ketika sedang naik ataupun sedang turun. Dengan pendekatan ini, para investor di pasar saham dapat memprediksi trend harga. Accumulation and distribution merupakan turunan dari indicator on balance volume (Devcic, 2019).

Perhitungan nilai accumulation and distribution adalah sebagai berikut :

a. Melakukan perbandingan antara opening dan closing price dari saham.

b. Melakukan perbandingan opening dan closing price dengan highest and lowest price pada periode tersebut.

c. Hasil perbandingan pada Langkah 2, dikalikan dengan volume transaksi.

Berikut contoh implementasi teknik accumulation and distribution pada saham PT Gudang Garam Indonesia Tbk:

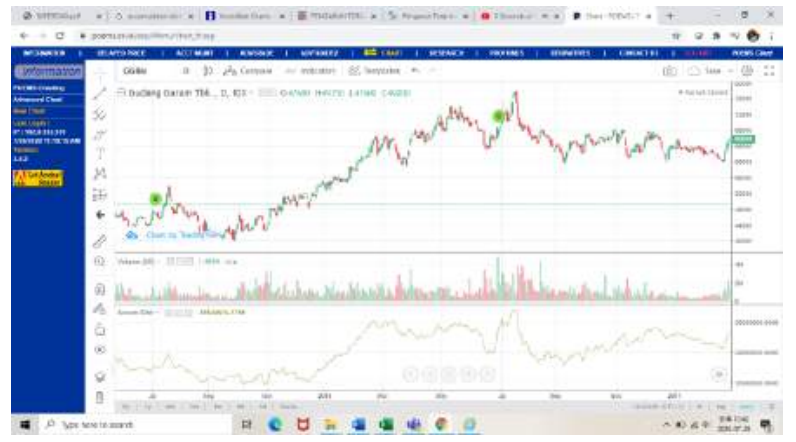

Gambar 1. Accumulation and Distributin PT Gudang Garam Indonesia Tbk.

Sumber : www.poems.com

Berdasarkan diagram diatas dapat dilihat hubungan antara harga saham dengan indicator accumualation and distribution line dari untuk saham GGRM (PT. Gudang Garam Indonesia Tbk.) terdapat beberapa trend perubahan harga yang dapat diidentifikasi melalui accumulation and distribution 
line yang digambarkan pada 3 trend perubahan harga. Selain itu secara pola, baik garis harga maupun garis volume memiliki pola yang serupa. Hal ini dapat disimpulkan bahwa pergerakan harga dari saham ini dipengaruhi oleh cashflow perdagangan di pasar. Sehingga pergerakan harga naik maupun turun, hal itu bergantung pada preferensi investor terhadap saham ini.

\subsection{Kerangka Konseptual}

Penelitian ini dilaksanakan dengan menggunakan kerangka konseptual sebagai berikut:

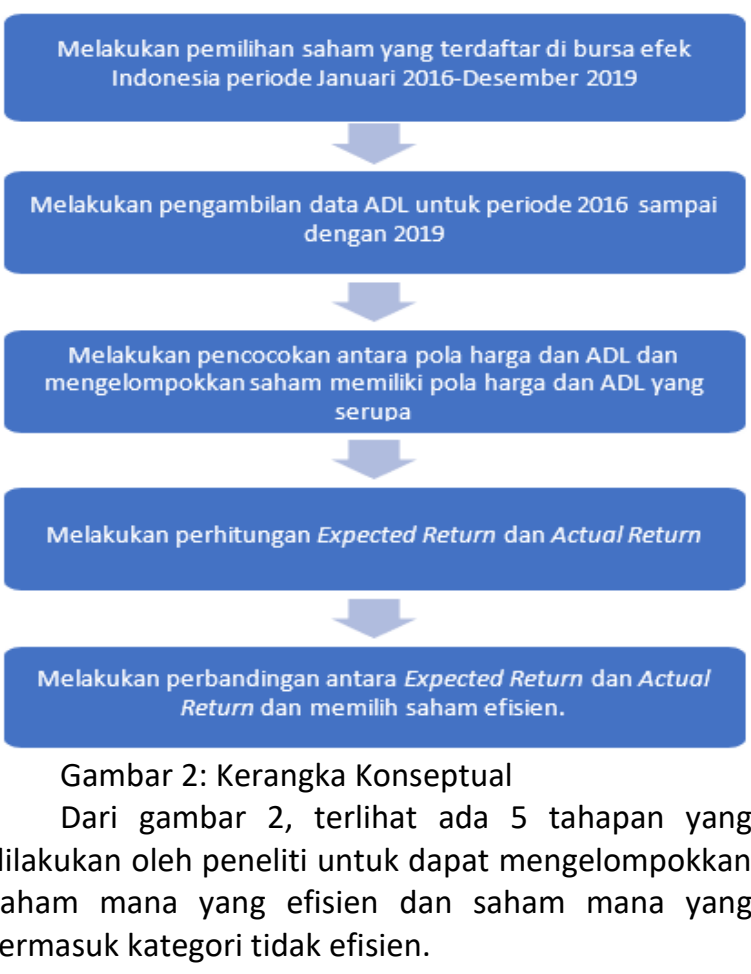

\section{METODE PENELITIAN}

\subsection{Rancangan Penelitian}

Penelitian ini menggunakan data seluruh saham yang terdaftar di Bursa Efek Indonesia pada periode tahun 2016-2019. Populasi dalam penelitian ini adalah 697 saham perusahaan yang terdaftar di bursa efek Indonesia. Pemilihan sampel dalam penelitian kali ini menggunakan metode purposive sampling dengan kriteria sebagai berikut:

a. Perusahaan terdaftar di Bursa Efek Indonesia selama periode tahun 2016-2019.

b. Memiliki garis ADL yang membentuk pola serupa dengan pola harga pada periode sample.

c. Diperdagangkan secara aktif dan wajar di bursa efek. Dengan demikian dapat dipastikan saham yang dipilih tidak pernah disuspen selama periode tahun 2016-2019.

d. Tidak berada di harga minimum perdagangan Rp. 50,- dalam kurun waktu yang lama.

\subsection{Definisi Operasional dan Pengukuran}

Berikut definisi operasional dan pengukuran yang digunakan dalam penelitian ini.

\section{a. Return Saham}

Return atau pengembalian merupakan imbal hasil yang diperoleh pada saat melakukan kegiatan investasi. Return yang perlu diperhitungkan dengan metode ini dibagi menjadi dua yaitu ada expected return dan actual return. Expected return merupakan harapan terhadap tingkat pengembalian sebuah saham, sementra actual return merupakan return sesungguhnya dari saham tersebut. Kedua hal ini bisa saja berbeda karena expected return memperhitungkan nilai masa lalu, sementara actual return melihat hasil yang diperoleh berdasarkan transaksi di pasar. (Jogiyanto, 2015)

Perhitungan return saham dapat menggunakan rumus berikut:

Keterangan:

$$
(R i)=\frac{C+P_{t}-P_{t-1}}{P_{t-1}}
$$

$\mathrm{C}=$ cashflow

(Ri) = return saham individual

Pt = harga pada periode sekarang

Pt-1 =harga pada periode sebelumnya

Pada perhitungan ini diasumsikan bahwa cashflow dari semua perusahaan adalah 0 , sehingga perhitungan hanya menggunakan hasil pebandingan harga saja.

b. Non diversible risk (Beta)

Perhitungan non diversible risk pada CAPM diukur dalam bentuk Beta $(\beta)$. Beta $(\beta)$ digambarkan sebagai suatu suatu ukuran risiko suatu saham terhadap perubahan harga saham di pasar. Dengan kata lain beta merupakan standar deviasi dari return saham yang dikaitkan dengan return pasar. Beta $(\beta)$ dapat dihitung dengan menggunakan melakukan pembagian antara covarian dan varian. Namun Beta ( $\beta$ ) juga dapat digambarkan sebagai slope antara return pasar dan return saham. Pada penelitian ini perhitungan beta menggunakan slope antara return saham dengan return market yang digambarkan dalam rumus sebagai berikut:

$$
\beta=\text { Slope }(Y, X)
$$

Keterangan:

$\mathrm{Y}=$ return saham

$\mathrm{X} \quad=$ return IHSG

c. Return Pasar

Return pasar dapat dihitung dengan menghitung tingkat keuntungan indeks saham gabungan dapat dilihat seperti berikut (Jogiyanto, 2015).

$$
R_{m}=\frac{I H S G_{t}-I H S G_{t-1}}{I H S G_{t-1}}
$$

Keterangan:

IHSGt = IHSG pada harga periode sekarang

IHSGt-1 = IHSG periode sebelumnya

d. Tingkat pengembalian bebas risiko (Rf)

Perhitungan tingkat pengembalian bebas risiko dilakukan dengan mengambil data $\mathrm{BI}$ rate dari 
periode 2016-2019. Perhitungan rate dilakukan dengan menggunakan metode Weighted Avarage dengan menggunakan rumus berikut (Jogiyanto, 2015) :

$$
R_{f}=\frac{P_{1} \times R_{1}+P_{2} \times \ldots+P_{n} \times R_{n}}{P_{1}+P_{2}+\cdots+P_{n}}
$$

Keterangan:

$\mathrm{P} 1, \mathrm{P} 2, \mathrm{Pn} \quad=$ Periode 1, Periode 2, Periode $\mathrm{n}$

$\mathrm{R} 1, \mathrm{R} 2, \mathrm{Rn} \quad=$ Return 1, Return 2, Periode $\mathrm{n}$

e. Tingkat pengembalian yang diharapkan (E (Ri)

Perhitungan expected return menggunakan Rumus CAPM sebagai berikut (Jogiyanto, 2015): $E(R i)=R f+\beta[E(R m)-R f]$

Keterangan:

$\mathrm{E}(\mathrm{Ri})$ : Tingkat pengembalian yang diharapkan Rf : Tingkat pengembalian bebas risiko

$\beta$ : Tingkat risiko sistematis masing-masing saham $\mathrm{E}(\mathrm{Rm})$ : Tingkat pengembalian yang diharapkan atas portofolio

f. Garis Pasar Sekuritas (Security Market Line (SML))

SML digunakan untuk memetakan hubungan antara expected retun dan risiko dengan cara melakukan perbandingan antara expected return dari perhitungan CAPM dengan nilai non-diversible risk atau beta $(\beta)$. Dari hubungan tersebut maka dapat ditarik suatu hubungan antara kedua komponen tersebut sehingga kita dapat melihat secara garis besar pola hubungan antara expected return dengan risiko saham tersebut. Penggambaran ini juga akan dilakukan dengan mengurutkan return terkecil agar dapat melihat pola hubungan dua komponen tersebut secara jelas.

\subsection{Teknik Analisis Data}

Penelitian ini menggunakan analisis data kuantitatif yaitu dengan cara melakukan perhitungan, menganalisis, dan menginterpretasikan data hasil perhitungan yang diperoleh untuk melakukan penentuan saham apa saja yang masuk dalam kategori efisien. Peneliti juga menyediakan beberapa grafik yang dapat membantu memvisualisasikan hasil penelitian agar dapat dimengerti dan diperoleh gambaran secara umum terhadap hasil penelitian yang diperoleh. Adapun Langkah-langkah yang dilakukan pada saat penelitian adalah sebagai berikut:

a. Melakukan perhitungan actual return per saham (Ri).

b. Melakukan perhitungan Return Pasar/Market $(\mathrm{Rm})$.

c. Melakukan perhitungan Risk Free (Rf) pada peride data yang dikumpulkan.

d. Melakukan perhitungan risiko non diversible dari masing-masing saham (Beta).

e. Melakukan perhitungan Expected Return [E(Ri)] dengan menggunakan rumusan CAPM. f. Melakukan mapping antara harga dan expected return yang diperoleh pada Security Market Line (SML).

g. Melakukan pengelompokan saham-saham efisien dan saham-saham tidak efisien, serta melakukan mapping antara actual return dan expected return saham-saham yang telah dihitung dengan metode CAPM. Pengambilan keputusan saham efisien dan tidak efisien dikelompokan dengan acuan sebagai berikut:

1) Jika saham memiliki nilai expected return diatas dari actual return maka akan dikelompokan sebagai saham tidak efisien $[\mathrm{Ri}<\mathrm{E}(\mathrm{Ri})]$.

2) Jika saham memiliki nilai expected return dibawah dari actual return maka akan dikelompokan sebagai saham efisien [Ri > $E(R i)]$.

h. Melakukan penggambaran hubungan antara garis SML dengan actual return dari saham. Untuk mempermudah visualisasi terhadap hasil perhitungan maka akan disajikan hubungan antara SML dengan garis actual return dari saham dari saham-saham yang dipilih.

\section{HASIL PENELITIAN DAN PEMBAHASAN}

\subsection{Deskripsi Data/Objek Penelitian \\ 4.1.1 Sample Penelitian}

Sample penelitian yang digunakan dalam penelitan ini adalah saham perusahaan terbuka yang diperdagangkan di bursa efek Indonesia. Dari data perusahaan terbuka yang terdaftar di Bursa Efek Indonesia, terdapat 697 total perusahaan per bulan Mei 2020. Berdasarkan data tersebut dilakukan pemilihan saham berdasarkan kriteria berikut:

a. Diperdagangkan di Bursa Efek Indonesia selama periode tahun 2016-2019. Berdasarkan kriteria tersebut diperoleh jumlah 488 saham perusahaan yang memenuhi.

b. Memiliki garis ADL yang membentuk pola serupa dengan pola harga pada periode sample. Garis ADL diperoleh dari www.poems.co.id dengan pemilihan indeks accumulation and distribution. Berdasarkan hasil hasil pencocokan garis ADL dan dan pola harga diperoleh 341 saham yang memiliki pola harga yang sesuai dengan pola garis ADL dan 147 saham yang memiliki pola garis yang tidak serupa.

c. Diperdagangkan secara aktif dan wajar di bursa efek. Dengan demikian dapat dipastikan saham yang dipilih tidak pernah dihentikan (suspend) selama periode tahun 2016-2019. Berdasarkan kriteria ini terdapat 202 saham yang diperdagangkan secara tidak wajar di Bursa Efek Indonesia dan 139 saham yang diperdagangkan secara wajar.

d. Tidak berada di harga minimum perdagangan Rp. 50,- dalam kurun waktu yang lama. 
Berdasarkan kreiteria ini terdapat 30 saham yang berada di harga Rp. 50,- dan 109 saham berada diatas harga Rp. 50,--

Berdasarkan kriteria-kriteria tersebut diperoleh 109 perusahaan yang memenuhi kriteria untuk digunakan sebagai sample perhitungan CAPM.

\subsubsection{Penggunaan harga untuk dasar perhitungan return}

Harga yang digunakan dalam perhitungan return saham mengguanakan adjusted closing price dari 109 sample perusahaan yang telah dipilih sebelumnya. Penggunaan adjusted closing price dipilih dengan pertimbangan berikut perdagangan saham ditutup sesuai dengan jadwal yang ditentukan oleh BEI namun setelah perdagangan masih terdapat penyesuian harga untuk perdagangan yang dilakukan mendekati penutupan pasar. Data adjusted closing price diperoleh dari www.yahoofinance.com.

\subsubsection{Market Return}

Index IHSG digunakan sebagai dasar perhitungan return pasar. Pemilihan IHSG dilakukan dengan pertimbangan bahwa sample yang digunakan berasal dari seluruh perusahaan terbuka yang terdaftar di Bursa Efek Indonesia. Data IHSG diperoleh dari laporan Bursa Efek Indonesia yang bisa diakses melalui www.yahoofinance.com. Berdasarkan data tersebut dapat dilihat bahwa sejak tahun 2016 IHSG terus mengalami kenaikan sampai dengan awal tahun 2018, kemudian mengalami sedikit penurunan dan kembali naik di tahun 2019. Nilai tertinggi berada di angka 6605.630859 dengan return tertinggi di angka $6,8 \%$ dan nilai terendah 4223.783203 dengan return terendah di $-7,8 \%$.

Suku Bunga Bank Indonesia ( $\mathrm{BI}$ Rate) digunakan untuk menghitung tingkat pengembalian bebas risiko atau risk free rate. Data ini diambil dari www.bps.go.id. Tabel 3 berikut adalah data $\mathrm{BI}$ rate bulan Januari 2016-Desember 2019.

\subsection{Analisis Data Penelitian}

Analisis data dilakukan dengan beberapa tahapan, yang dimulai dengan menghitung return pasar saham sampai menggambar SML untuk kemudian mengelompokkan saham menjadi kelompok saham efisien dan saham yang tidak efisien.

\subsubsection{Return Pasar}

Perhitungan return pasar dilakukan dapat dilakukan dengan menghitung return index IHSG yang mana IHSG merepresentasikan perdagangan saham di Bursa Efek Indonesia. Perhitungan return yang dilkukan adalah return bulanan dengan cara mencari presentasi keuntungan/kerugian dari selisih IHSG di bulan $n+1$ dan dibandingkan dengan index pada bulan ke $n$. Hasil perhitungan tersebut dapat dilihat pada tabel berikut:

Tabel 1: Return Pasar

\begin{tabular}{|c|c|c|}
\hline DATE & JKSE & RJKSE \\
\hline 1-Jan-16 & 4615.025879 & \\
\hline 1-Feb-16 & 4770.814453 & $3.4 \%$ \\
\hline 1-Mar-16 & 4845.227051 & $1.6 \%$ \\
\hline 1-Apr-16 & 4838.439453 & $-0.1 \%$ \\
\hline 1-May-16 & 4796.726563 & $-0.9 \%$ \\
\hline 1-Jun-16 & 5016.498535 & $4.6 \%$ \\
\hline 1-Jul-16 & 5215.839355 & $4.0 \%$ \\
\hline 1-Aug-16 & 5385.922363 & $3.3 \%$ \\
\hline 1-Sep-16 & 5364.64502 & $-0.4 \%$ \\
\hline 1-Oct-16 & 5422.541992 & $1.1 \%$ \\
\hline 1-Nov-16 & 5148.910156 & $-5.0 \%$ \\
\hline 1-Dec-16 & 5296.710938 & $2.9 \%$ \\
\hline 1-Jan-17 & 5294.103027 & $0.0 \%$ \\
\hline 1-Feb-17 & 5386.691895 & $1.7 \%$ \\
\hline 1-Mar-17 & 5568.105957 & $3.4 \%$ \\
\hline 1-Jul-18 & 5936.442871 & $2.4 \%$ \\
\hline 1-Aug-18 & 6018.459961 & $1.4 \%$ \\
\hline 1-Sep-18 & 5976.553223 & $-0.7 \%$ \\
\hline 1-Oct-18 & 5831.649902 & $-2.4 \%$ \\
\hline 1-Nov-18 & 6056.124023 & $3.8 \%$ \\
\hline 1-Dec-18 & 6194.498047 & $2.3 \%$ \\
\hline 1-Jan-19 & 6532.969238 & $5.5 \%$ \\
\hline 1-Feb-19 & 6443.348145 & $-1.4 \%$ \\
\hline 1-Mar-19 & 6468.754883 & $0.4 \%$ \\
\hline 1-Apr-17 & 5685.297852 & $2.1 \%$ \\
\hline 1-May-17 & 5738.154785 & $0.9 \%$ \\
\hline 1-Jun-17 & 5829.708008 & $1.6 \%$ \\
\hline 1-Jul-17 & 5840.938965 & $0.2 \%$ \\
\hline 1-Aug-17 & 5864.059082 & $0.4 \%$ \\
\hline 1-Sep-17 & 5900.854004 & $0.6 \%$ \\
\hline 1-Oct-17 & 6005.78418 & $1.8 \%$ \\
\hline 1-Nov-17 & 5952.138184 & $-0.9 \%$ \\
\hline 1-Dec-17 & 6355.653809 & $6.8 \%$ \\
\hline 1-Jan-18 & 6605.630859 & $3.9 \%$ \\
\hline 1-Feb-18 & 6597.217773 & $-0.1 \%$ \\
\hline 1-Mar-18 & 6188.986816 & $-6.2 \%$ \\
\hline 1-Apr-18 & 5994.595215 & $-3.1 \%$ \\
\hline 1-May-18 & 5983.586914 & $-0.2 \%$ \\
\hline 1-Jun-18 & 5799.236816 & $-3.1 \%$ \\
\hline 1-Apr-19 & 6455.352051 & $-0.2 \%$ \\
\hline 1-May-19 & 6209.117188 & $-3.8 \%$ \\
\hline 1-Jun-19 & 6358.628906 & $2.4 \%$ \\
\hline 1-Jul-19 & 6390.504883 & $0.5 \%$ \\
\hline 1-Aug-19 & 6328.470215 & $-1.0 \%$ \\
\hline
\end{tabular}


perhitungan nilai Beta $(\beta)$ dilakukan dengan cara menghitung slope antara return pasar dengan return per masing-masing saham. Berdasarkan hasil pengolahan data tersebut maka diperoleh data sebagai berikut:

Tabel 3: Perthitungan Risiko Sistematis

\begin{tabular}{|c|c|c|c|c|c|}
\hline No & Kode & $\beta$ & No & Kode & $\beta$ \\
\hline 1 & AALI & -1.301 & 16 & BATA & 0.082 \\
\hline 2 & ACST & 1.034 & 17 & BBCA & 1.076 \\
\hline 3 & ADHI & 2.363 & 18 & BBKP & 2.240 \\
\hline 4 & ADMF & 0.796 & 19 & BBNI & 1.870 \\
\hline 5 & AKRA & 1.654 & 20 & BBRI & 1.521 \\
\hline 6 & ALMI & 0.765 & 21 & BBTN & 1.729 \\
\hline 7 & AMRT & -0.402 & 22 & BBYB & 1.940 \\
\hline 8 & APIC & -0.438 & 23 & BDMN & 2.330 \\
\hline 9 & APLN & 1.666 & 24 & BEST & 2.683 \\
\hline 10 & ARNA & 0.642 & 25 & BJBR & 1.981 \\
\hline 11 & ASGR & 0.248 & 26 & BMRI & 1.214 \\
\hline 12 & ASII & 1.338 & 27 & BMTR & 1.912 \\
\hline 13 & ASMI & 0.894 & 28 & BNBA & 0.712 \\
\hline 14 & ASSA & 1.854 & 29 & BNGA & 2.570 \\
\hline 15 & AUTO & 0.804 & 30 & BNLI & 1.969 \\
\hline 31 & BRNA & 0.351 & 57 & INDF & 1.107 \\
\hline 32 & BRPT & 1.717 & 58 & INTP & 1.796 \\
\hline 33 & BSDE & 1.465 & 59 & ISAT & 2.150 \\
\hline 34 & BWPT & 1.880 & 60 & ITMG & 2.708 \\
\hline 35 & CLPI & 0.800 & 61 & JPFA & 1.732 \\
\hline 36 & CMNP & -0.096 & 62 & JSMR & 0.986 \\
\hline 37 & CPIN & 0.899 & 63 & KBLI & 1.550 \\
\hline 38 & CTRA & 1.319 & 64 & KLBF & 1.310 \\
\hline 39 & DLTA & 0.077 & 65 & KRAS & 1.375 \\
\hline 40 & DNAR & -1.365 & 66 & LPCK & 2.180 \\
\hline 41 & DNET & -0.090 & 67 & LPPF & 1.619 \\
\hline 42 & DOID & 3.198 & 68 & LSIP & 0.498 \\
\hline 43 & DSNG & -0.221 & 69 & MAIN & 1.857 \\
\hline 44 & DVLA & 0.003 & 70 & MCOR & 0.880 \\
\hline 45 & ERAA & 1.782 & 71 & MICE & 0.300 \\
\hline 46 & EXCL & 0.119 & 72 & MLBI & -0.186 \\
\hline 47 & FASW & -0.098 & 73 & MPMX & 0.085 \\
\hline 48 & GGRM & 1.218 & 74 & $\mathrm{MYOH}$ & 0.843 \\
\hline 49 & GIAA & 1.074 & 75 & MYOR & 0.070 \\
\hline 50 & HEXA & -1.181 & 76 & PANS & 1.021 \\
\hline 51 & HMSP & 2.859 & 77 & PGAS & 1.830 \\
\hline 52 & HRUM & 2.347 & 78 & PNBN & 1.333 \\
\hline 53 & ICBP & 0.721 & 79 & PNLF & 1.019 \\
\hline 54 & INAF & 2.688 & 80 & PTPP & 2.895 \\
\hline 55 & $\mathrm{INCl}$ & -0.012 & 81 & PWON & 1.149 \\
\hline
\end{tabular}




\begin{tabular}{|c|c|c|c|c|r|}
56 & INCO & 1.534 & 82 & RALS & 1.210 \\
\hline 83 & RANC & 0.349 & 97 & TBLA & 1.263 \\
\hline 84 & ROTI & 0.619 & 98 & TELE & 1.464 \\
\hline 85 & SAME & 0.441 & 99 & TINS & 2.234 \\
\hline 86 & SCCO & 0.926 & 100 & TLKM & 0.447 \\
\hline 87 & SCMA & 1.704 & 101 & TOTL & 1.345 \\
\hline 88 & SGRO & 0.250 & 102 & TSPC & 0.522 \\
\hline 89 & SIDO & 0.250 & 103 & TURI & 0.337 \\
\hline 90 & SIMP & 1.144 & 104 & ULTJ & -0.484 \\
\hline 91 & SMBR & 4.080 & 105 & UNTR & 0.926 \\
\hline 92 & SMGR & 1.993 & 106 & UNVR & 1.167 \\
\hline 93 & SMRA & 2.229 & 107 & WIKA & 2.375 \\
\hline 94 & SMSM & 0.608 & 108 & WSKT & 2.549 \\
\hline 95 & SOCI & 1.579 & 109 & WTON & 1.368 \\
\hline 96 & TARA & -0.105 & & & \\
\hline SUm & & & &
\end{tabular}

Sumber: Diolah

Berdasarkan hasil perhitungan menunjukkan rata-rata $\beta$ bernilai lebih dari $1(1,153>1)$ sehingga secara umum 109 saham perusahaan yang dijadikan sampel penelitian memiliki risiko sistematis yang tinggi dan cenderung aktif dalam merespon perubahan harga pasar. Rata-rata tinggi rendahnya $\beta \mathrm{i}$ berbanding terbalik dengan tingkat pengembalian saham (return). Semakin tinggi nilai $\beta \mathrm{i}$, tingkat pengembalian saham yang diharapkan semakin kecil dan begitu juga sebaliknya semakin rendah $\beta \mathrm{i}$ maka tingkat pengembalian saham yang diharapkan semakin besar.

\subsubsection{Hasil Analisis Tingkat Pengembalian yang Diharapkan [ERi] \\ Berdasarkan penjelasan data yang sudah} diinformasikan sebelumnya, telah dilakukan perhitungan expected return [E(Ri)]. Metode CAPM sendiri digunakan untuk menghitung tingkat pengembalian yang diharapkan dengan menggunakan variabel tingkat pengembalian bebas risiko (Rf), rata-rata tingkat pengembalian pasar $[E(R m)]$, dan juga risiko sistematis masing-masing saham. Hasil perhitungan tingkat pengembalian yang diharapkan adalah sebagai berikut:

Tabel 4: Perhitungan Expected Return (Lihat Lampiran 1)

Berdasarkan tabel 4, jumlah rata-rata tingkat pengembalian saham yang diharapkan sebesar 0,00462 . Angka 0,00462 diperoleh dengan cara membagi jumlah total tingkat pengembalian yang diharapkan sebesar 0,23565 dengan jumlah saham perusahaan yang dijadikan sampel penelitian yaitu 51 saham.

\subsubsection{Penggambaran Grafik Security Market Line} (SML)
Security Market Line (SML) atau garis pasar sekuritas (GPS) merupakan penggambaran grafis model CAPM. SML menunjukkan hubungan antara besarnya risiko sistematis dengan tingkat pengembalian yang diharapkan. Berikut ini disajikan gambar grafik SML dari 109 saham perusahaan yang dijadikan sampel penelitian. Berdasarkan hasil penelitian yang dilakukan sebelumnya, dapat diketahui bahwa semakin besar risiko sistematis/beta $(\beta)$, semakin besar pula tingkat pengembalian yang diharapkan $[E(R i)]$. Hal ini sesuai dengan prinsip risk and return yang mana semakin besar risiko yang akan ditanggung oleh investor, maka semakin besar pula return yang diharapkan. Hal tersebut digambarkan oleh grafik SML berikut:

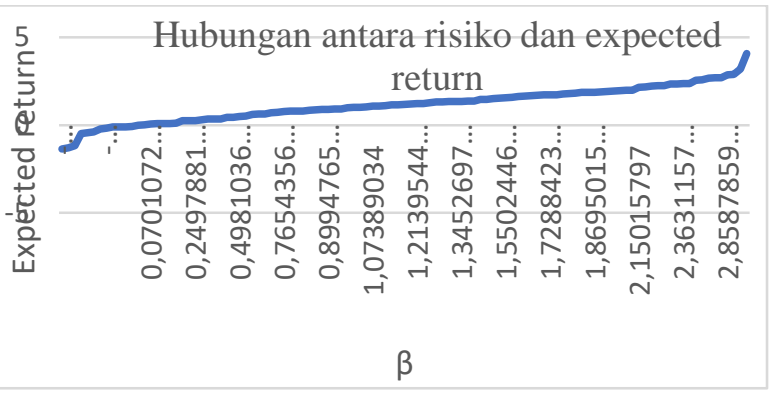

Gambar 3: Security Market Line

\subsubsection{Pengelompokan Saham-saham Efisien dan Keputusan Investasi}

Saham efisien adalah saham dengan tingkat pengembalian individu lebih besar daripada tingkat pengembalian yang diharapkan [(Ri) > E(Ri)]. Saham tidak efisien adalah saham dengan tingkat pengembalian individu lebih kecil daripada tingkat pengembalian yang diharapkan $[(R i)<E(R i)]$. Sahamsaham efisien jika dilihat pada grafik SML terletak di atas garis SML. Berikut tabel hasil perbandingan $\mathrm{E}(\mathrm{Ri})$ dengan Ri per masing masing saham:

Tabel 5: Pengelompokan Saham Efisien dan Tidak Efisien

(Lihat Lampiran 2)

Berdasarkan data pada table tersebut dapat disimpulkan bahwa terdapat 54 saham yang tergolong efisien dan 55 saham yang tergolong tidak efisien. Secara grafik hubungan antara actual return dan expected return dapat digambarkan sebagai berikut : 


\section{Chart Title}

4

2

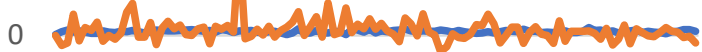

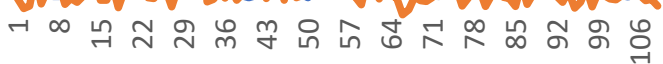

$-2 \longrightarrow$ Expected Retur Avrage return/year

Saham yang dapat digolongkan dengan return diatas expected return. Sementara saham dengan return dibawah expected return, digolongkan sebagai saham yang tidak efisien.

\subsubsection{Diskusi dan Pembahasan}

Hasil penelitian ini menunjukkan bahwa dari 109 saham perusahaan yang terpilih menjadi sample, maka ditemukan 54 saham dikategorikan sebagai saham efisien dan 55 saham dikategorikan saham tidak efisien. Temuan ini membuktikan kembali kemampuan model CAPM untuk memprediksi mengenai keseimbangan perkiraaan imbal hasil terhadap portofolio yang dimiliki oleh investor. Penelitian ini mempertimbangkan volume perdagangan saham dalam pengambilan sampel karena volume perdagangan merupakan salah satu faktor yang dapat mempengaruhi volatilitas harga saham. Sesuai dengan hukum penawaran permintaan, semakin banyak permintaan, maka harga akan meningkat dan sebaliknya. Hukum ini juga berlaku untuk perdagangan saham. Selain volume, saham yang diteliti adalah saham-saham yang diperdagangkan secara wajar, sehingga hasil ini tidak berlaku untuk memprediksi saham-saham yang diperdagangkan dengan tidak wajar.

Temuan penelitian ini dapat memberikan informasi bagi investor mengenai kelompok saham undervalued (return saham aktual lebih tinggi daripada expected return) atau overvalued (return saham aktual lebih rendah daripada expected return). Informasi tersebut dapat dimanfaatkan oleh investor untuk mengatur kembali portofolio investasi mereka. Saham-saham undervalued dapat menjadi sebuah pilihan investasi bagi investor karena suatu saat saham ini akan meningkat menuju nilai wajar dan sebaliknya saham overvalued bisa dipertimbangkan untuk dijual, karena suatu saat akan ada kemungkinan harganya akan turun.

Hasil penelitian ini sejalan dengan penelitian Andriyani et al (2016), serta Susanti dan Putra (2018) yang melakukan studi pada saham yang termasuk dalam kategori LQ45 dan juga penelitian Dinahastuti (2019) yang melakukan penelitian pada saham yang tergabung dalam Indeks Nikkei 225 Riset-riset tersebut membuktikan bahwa model CAPM efektif dalam menentukan saham yang efisien dan tidak efisien. Akan tetapi hasil penelitian ini tidak sejalan dengan penelitian Afolabi et al (2017) di bursa efek Nigeria, dimana tidak terdapat bukti konklusif penggunaan model CAPM pada saham-saham di Nigeria. Perbedaan hasil ini mungkin disebabkan oleh perbedaan tingkat efisiensi pasar modal pada tiap negara. Penelitian ini memperkuat hasil penelitian Astuty (2017) di bursa Indonesia dan Mazouz et al (2012) di bursa Inggris yang menemukan terdapat hubungan antara risiko sistematis dengan harga saham. Terdapat trade-off antara risiko dan expected return dalam berinvestasi saham dan hal ini merupakan hal yang harus dipertimbangkan oleh investor atau calon investor.

\section{KESIMPULAN, KETERBATASAN DAN IMPLIKASI}

Berdasarkan hasil analisis data yang dilakukan, kesimpulan dari penelitian ini adalah sebagai berikut: (a) Terdapat hubungan linear antara risiko sistematis dengan expected return. Hal ini dibuktikan dengan penggambaran pada garis $\mathrm{SML}$, yang mana semakin $\beta$, maka semakin besar juga nilai dari expected return saham tersebut. Hal ini sejalan dengan teori mengenai hubungan risk dan return dimana, semakin besar risiko yang diambil maka semakin besar pula tingkat pengembalian yang diharapkan dari suatu investasi. (b) Terdapat 54 saham perusahaan yang termasuk dalam kategori saham efisien dan 55 saham perusahaan yang termasuk dalam kategori saham tidak efisien dari 109 saham perusahaan yang dijadikan sampel penelitian. Saham-saham efisien memiliki nilai Ri lebih besar daripada $E(R i)$ atau [Ri $>E(R i)$. Sedangkan saham-saham tidak efiesien memiliki nilai Ri lebih kecil daripada $\mathrm{E}(\mathrm{Ri})$ atau $[\mathrm{Ri}<\mathrm{E}(\mathrm{Ri})]$.

Keterbatasan penelitian ini adalah (a) Tingkat pengembalian yang dihitung hanyalah tingkat pengembalian berdasarkan capital gain saja dan tidak memperhitungkan dividen yang diperoleh selama periode tersebut. (b) Perhitungan acuan harga menggunakan data harga bulanan, sehingga untuk return yang didapat lebih menunjukan return dari investasi jangka pendek. Perhitungan yang berbeda bisa saja diperoleh apabila harga acuan yang digunakan adalah harga harian atau tahunan.

Hasil penelitian ini menyajikan saham-saham mana yang tergolong efisien dan yang tidak efisien untuk periode 2016-2019. Hasil ini diharapkan dapat dijadikan referensi dan tambahan informasi bagi para investor maupun calon investor yang akan melakukan investasi saham. Sangat penting bagi investor untuk menginvestasikan kelebihan dana yang dimiliki pada saham-saham yang efisien agar risiko yang akan dihadapi dapat diminimalisir dengan baik, sehingga tujuan investor untuk mendapatkan return yang diharapkan dapat tercapai. Peneliti selanjutnya dapat mengambil periode tahun 2020, dimana pada tahun tersebut terjadi pandemic Covid 
19 diseluruh dunia sehingga perekonomian seluruh dunia termasuk Indonesia mengalami perlemahan yang signifikan. Peneliti dapat melihat dampak perlemahan ekonomi terhadap saham-saham yang efisien pada periode ini. Peneliti juga dapat memperluas cakupan dengan mengambil sahamsaham pada bursa efek di negara lain dengan tingkat efisiensi yang berbeda.

\section{DAFTAR PUSTAKA}

Afolabi, T., Njogo, B., Areghan, I., Olugbenle, A., \& Olusesi, H. (2017). Capital Assets Pricing Model: Evidence from the Nigerian Stock Exchange. International Journal of English LEterature and Sosial Sciences (JIELS), Vol. 2, Issue 6.

Andriyani, L., Farida, F., \& Machfiroh, D. (2016). Analisis Komparatif Pembentukan Portofolio Optimal menggunakan Capital Assets Pricing Model dan Stochastic Dominance. Jurnal Analisis Bisnis Ekonomi Vol. 14, No.1, 19-33.

Asuty, P. (2017). The Influence of Fundamental Factors and Systematic Risk to Stock Prices on Companies Listed in the Indonesian Stock Exchange. European Research Studies Journal, Volume XX, Issue 4A, 230-240.

Bodie, Z., Kane, A., \& Marcus, A. J. (2018). Investments, $11^{\text {th }}$ edition. Mc Graw Hill.

Chen, J. M. (2017). Econophysics and Capital Asset Pricing - Splitting the Atom of Systematic Risk. Switzerland: Springer.

Christiana, A. M., Septiana, E., \& Mamduch. (2016). The Empriical Relationship between Stock Return adn Trading Volume based on Stoc Market Cycles. Indonesia Capital Market Review, Volume 8, 46 - 57.

Dechow, P., Sloan, R., \& Zha, J. (2014). Stock Prices and Earnings: A History of Research. Annual Review of Financial Economics, Volume 6, No.1, 343 - 363.

Devcic, J. (2019, November 13). Trend-Spotting with the Accumulation / Distribution Line. Retrieved from Investopedia: https://www.investopedia. com/articles/trading/08/accumulationdistribution-line.asp

Dewi, N. I., \& Suaryana. (2016). Pengaruh Volume Perdagangan Saham, Leveraged dan Tingkat Suku Bunga terhadap Volatilitas Harga Saham. E-Jurnal Akuntansi, Volume 17 No.2.

Dinahastuti, D. (2019). Menguji Model CPAM dalam Menentukan Harga Saham di Pasar Modal. Jurnal Akuntansi, Volume 14, No.1.

Edwards, R., Mage, J., \& Bassetti, W. (2019). Technical Analysis of Stock Trend, $11^{\text {th }}$ edition. New York: Routledge.

Effendi, E. S., \& Hermanto, S. B. (2017). Pengaruh Rasio Keuangan dan Volume Perdagangan terhadap Return Saham. Jurnal Ilmu dan Riset Akuntansi, Volume 6, No. 11.
Gitman, L. J., \& Zutter, C. J. (2012). Principles of Managerial Finance, $13^{\text {th }}$ edition. San Fransisco: Pearson.

Jogiyanto, H. (2015). Teori Portofolio dan Analisis Investasi, Edisi 10. Yogyakarta: BPFE.

Kothari, S. (2001). Capital markets Research in Accounting. Journal of Accounting and Economics, Volume 31 (1-3), 105-231.

Lintner, J. (1965). The Valuation of Risk Assets and The Selection of Risky Investments in Stock Portfolios and Capital Budgets. Review of Economics and Statistics, Vol. 47, No.1, 13-37.

Marty, W. (2015). Portfolio Analysis - An Introduction to Return and Risk Measurment. New York: Springer.

Mazouz, K., Alrabadi, D. W., \& Yin, S. (2012). Systematic Liquidity Risk adn Stock Price Reaction to Shocks. Accounting and Finance, Volume 52, Issue 2, 467 - 493.

Melicher, R. W., \& Norton, E. A. (2017). Introduction to Finance. 16th Edition: Wiley.

Norken, I., Purbawijaya, I., \& Saputra, I. (2015). Pengantar Analisis dan Manajemen Risiko pada Proyek Konstruksi. Denpasar: Universitas Udayana Press.

Rossi, Mateo (2016). The Capital Asset Pricing Model: A Critical Literature Review. Global Business and Economics Review, Vol. 18. No.5, 604615.

Sharpe, W. (1964). The Capital Asset Prices: A Theory of Market Equilibrium Under Conditions of Risk. Journal of Finance, Vol.19 No. 3, 425442.

Singh, S., Jain, P., \& Yadav, S. S. (2016). Equity Markets in India Returns, Risk and Price Multiples. Singapore: Springer.

Susanti, N., \& Putra, O. E. (2018). Penerapan CAPM terhadap Keputusan Investasi pada Indeks LQ45 periode 2012-2016. Jurnal Muara Ilmu Ekonomi dan Bisnis, Volume 2, No.2, 366 376.

Thalassinos, I., \& Politis, D. (2012). The Evaluation of the USD currency and the oil prices: A VAR Analysis. European Research Studies Journal, Volume 15, No.2, 137-146. 
Tabel 4: Perhitungan Expected Return

\begin{tabular}{|c|c|c|c|c|c|c|c|}
\hline No & $\begin{array}{c}\text { Kode } \\
\text { Perusahaan }\end{array}$ & $R f$ & $\beta$ & $E(R m)$ & $E(R m)-R f$ & $\beta^{*}(E(R m)-R f)$ & $\begin{array}{c}E(R i)=R f \\
+\beta i \\
{[E(R m)-} \\
R f]\end{array}$ \\
\hline 1 & AALI & 0.053 & -1.301 & 0.083 & 0.029 & -0.038 & 0.015 \\
\hline 2 & ACST & 0.053 & 1.034 & 0.083 & 0.029 & 0.030 & 0.084 \\
\hline 3 & ADHI & 0.053 & 2.363 & 0.083 & 0.029 & 0.070 & 0.123 \\
\hline 4 & ADMF & 0.053 & 0.796 & 0.083 & 0.029 & 0.023 & 0.077 \\
\hline 5 & AKRA & 0.053 & 1.654 & 0.083 & 0.029 & 0.049 & 0.102 \\
\hline 6 & ALMI & 0.053 & 0.765 & 0.083 & 0.029 & 0.023 & 0.076 \\
\hline 7 & AMRT & 0.053 & -0.402 & 0.083 & 0.029 & -0.012 & 0.041 \\
\hline 8 & APIC & 0.053 & -0.438 & 0.083 & 0.029 & -0.013 & 0.040 \\
\hline 9 & APLN & 0.053 & 1.666 & 0.083 & 0.029 & 0.049 & 0.102 \\
\hline 10 & ARNA & 0.053 & 0.642 & 0.083 & 0.029 & 0.019 & 0.072 \\
\hline 11 & ASGR & 0.053 & 0.248 & 0.083 & 0.029 & 0.007 & 0.061 \\
\hline 12 & ASII & 0.053 & 1.338 & 0.083 & 0.029 & 0.039 & 0.093 \\
\hline 13 & ASMI & 0.053 & 0.894 & 0.083 & 0.029 & 0.026 & 0.080 \\
\hline 14 & ASSA & 0.053 & 1.854 & 0.083 & 0.029 & 0.055 & 0.108 \\
\hline 15 & AUTO & 0.053 & 0.804 & 0.083 & 0.029 & 0.024 & 0.077 \\
\hline 16 & BATA & 0.053 & 0.082 & 0.083 & 0.029 & 0.002 & 0.056 \\
\hline 17 & BBCA & 0.053 & 1.076 & 0.083 & 0.029 & 0.032 & 0.085 \\
\hline 18 & BBKP & 0.053 & 2.240 & 0.083 & 0.029 & 0.066 & 0.119 \\
\hline 19 & BBNI & 0.053 & 1.870 & 0.083 & 0.029 & 0.055 & 0.108 \\
\hline 20 & BBRI & 0.053 & 1.521 & 0.083 & 0.029 & 0.045 & 0.098 \\
\hline 21 & BBTN & 0.053 & 1.729 & 0.083 & 0.029 & 0.051 & 0.104 \\
\hline 22 & BBYB & 0.053 & 1.940 & 0.083 & 0.029 & 0.057 & 0.110 \\
\hline 23 & BDMN & 0.053 & 2.330 & 0.083 & 0.029 & 0.069 & 0.122 \\
\hline 24 & BEST & 0.053 & 2.683 & 0.083 & 0.029 & 0.079 & 0.132 \\
\hline 25 & BJBR & 0.053 & 1.981 & 0.083 & 0.029 & 0.058 & 0.112 \\
\hline 26 & BMRI & 0.053 & 1.214 & 0.083 & 0.029 & 0.036 & 0.089 \\
\hline 27 & BMTR & 0.053 & 1.912 & 0.083 & 0.029 & 0.056 & 0.110 \\
\hline 28 & BNBA & 0.053 & 0.712 & 0.083 & 0.029 & 0.021 & 0.074 \\
\hline 29 & BNGA & 0.053 & 2.570 & 0.083 & 0.029 & 0.076 & 0.129 \\
\hline 30 & BNLI & 0.053 & 1.969 & 0.083 & 0.029 & 0.058 & 0.111 \\
\hline 31 & BRNA & 0.053 & 0.351 & 0.083 & 0.029 & 0.010 & 0.064 \\
\hline 32 & BRPT & 0.053 & 1.717 & 0.083 & 0.029 & 0.051 & 0.104 \\
\hline 33 & BSDE & 0.053 & 1.465 & 0.083 & 0.029 & 0.043 & 0.096 \\
\hline 34 & BWPT & 0.053 & 1.880 & 0.083 & 0.029 & 0.055 & 0.109 \\
\hline 35 & CLPI & 0.053 & 0.800 & 0.083 & 0.029 & 0.024 & 0.077 \\
\hline 36 & CMNP & 0.053 & -0.096 & 0.083 & 0.029 & -0.003 & 0.050 \\
\hline 37 & CPIN & 0.053 & 0.899 & 0.083 & 0.029 & 0.026 & 0.080 \\
\hline 38 & CTRA & 0.053 & 1.319 & 0.083 & 0.029 & 0.039 & 0.092 \\
\hline 39 & DLTA & 0.053 & 0.077 & 0.083 & 0.029 & 0.002 & 0.056 \\
\hline 40 & DNAR & 0.053 & -1.365 & 0.083 & 0.029 & -0.040 & 0.013 \\
\hline 41 & DNET & 0.053 & -0.090 & 0.083 & 0.029 & -0.003 & 0.051 \\
\hline
\end{tabular}




\begin{tabular}{|c|c|c|c|c|c|c|c|}
\hline 42 & DOID & 0.053 & 3.198 & 0.083 & 0.029 & 0.094 & 0.147 \\
\hline 43 & DSNG & 0.053 & -0.221 & 0.083 & 0.029 & -0.006 & 0.047 \\
\hline 44 & DVLA & 0.053 & 0.003 & 0.083 & 0.029 & 0.000 & 0.053 \\
\hline 45 & ERAA & 0.053 & 1.782 & 0.083 & 0.029 & 0.052 & 0.106 \\
\hline 46 & EXCL & 0.053 & 0.119 & 0.083 & 0.029 & 0.004 & 0.057 \\
\hline 47 & FASW & 0.053 & -0.098 & 0.083 & 0.029 & -0.003 & 0.050 \\
\hline 48 & GGRM & 0.053 & 1.218 & 0.083 & 0.029 & 0.036 & 0.089 \\
\hline 49 & GIAA & 0.053 & 1.074 & 0.083 & 0.029 & 0.032 & 0.085 \\
\hline 50 & HEXA & 0.053 & -1.181 & 0.083 & 0.029 & -0.035 & 0.018 \\
\hline 51 & HMSP & 0.053 & 2.859 & 0.083 & 0.029 & 0.084 & 0.137 \\
\hline 52 & HRUM & 0.053 & 2.347 & 0.083 & 0.029 & 0.069 & 0.122 \\
\hline 53 & ICBP & 0.053 & 0.721 & 0.083 & 0.029 & 0.021 & 0.074 \\
\hline 54 & INAF & 0.053 & 2.688 & 0.083 & 0.029 & 0.079 & 0.132 \\
\hline 55 & $\mathrm{INCl}$ & 0.053 & -0.012 & 0.083 & 0.029 & -0.000 & 0.053 \\
\hline 56 & INCO & 0.053 & 1.534 & 0.083 & 0.029 & 0.045 & 0.098 \\
\hline 57 & INDF & 0.053 & 1.107 & 0.083 & 0.029 & 0.033 & 0.086 \\
\hline 58 & INTP & 0.053 & 1.796 & 0.083 & 0.029 & 0.053 & 0.106 \\
\hline 59 & ISAT & 0.053 & 2.150 & 0.083 & 0.029 & 0.063 & 0.117 \\
\hline 60 & ITMG & 0.053 & 2.708 & 0.083 & 0.029 & 0.080 & 0.133 \\
\hline 61 & JPFA & 0.053 & 1.732 & 0.083 & 0.029 & 0.051 & 0.104 \\
\hline 62 & JSMR & 0.053 & 0.986 & 0.083 & 0.029 & 0.029 & 0.082 \\
\hline 63 & KBLI & 0.053 & 1.550 & 0.083 & 0.029 & 0.046 & 0.099 \\
\hline 64 & KLBF & 0.053 & 1.310 & 0.083 & 0.029 & 0.039 & 0.092 \\
\hline 65 & KRAS & 0.053 & 1.375 & 0.083 & 0.029 & 0.041 & 0.094 \\
\hline 66 & LPCK & 0.053 & 2.180 & 0.083 & 0.029 & 0.064 & 0.117 \\
\hline 67 & LPPF & 0.053 & 1.619 & 0.083 & 0.029 & 0.048 & 0.101 \\
\hline 68 & LSIP & 0.053 & 0.498 & 0.083 & 0.029 & 0.015 & 0.068 \\
\hline 69 & MAIN & 0.053 & 1.857 & 0.083 & 0.029 & 0.055 & 0.108 \\
\hline 70 & MCOR & 0.053 & 0.880 & 0.083 & 0.029 & 0.026 & 0.079 \\
\hline 71 & MICE & 0.053 & 0.300 & 0.083 & 0.029 & 0.009 & 0.062 \\
\hline 72 & MLBI & 0.053 & -0.186 & 0.083 & 0.029 & -0.005 & 0.048 \\
\hline 73 & MPMX & .053 & 0.085 & 0.083 & 0.029 & 0.002 & 0.056 \\
\hline 74 & $\mathrm{MYOH}$ & 0.053 & 0.843 & 0.083 & 0.029 & 0.025 & 0.078 \\
\hline 75 & MYOR & 0.053 & 0.070 & 0.083 & 0.029 & 0.002 & 0.055 \\
\hline 76 & PANS & 0.053 & 1.021 & 0.083 & 0.029 & 0.030 & 0.083 \\
\hline 77 & PGAS & 0.053 & 1.830 & 0.083 & 0.029 & 0.054 & 0.107 \\
\hline 78 & PNBN & 0.053 & 1.333 & 0.083 & 0.029 & 0.039 & 0.093 \\
\hline 79 & PNLF & 0.053 & 1.019 & 0.083 & 0.029 & 0.030 & 0.083 \\
\hline 80 & PTPP & 0.053 & 2.895 & 0.083 & 0.029 & 0.085 & 0.138 \\
\hline 81 & PWON & 0.053 & 1.149 & 0.083 & 0.029 & 0.034 & 0.087 \\
\hline 82 & RALS & 0.053 & 1.210 & 0.083 & 0.029 & 0.036 & 0.089 \\
\hline 83 & RANC & 0.053 & 0.349 & 0.083 & 0.029 & 0.010 & 0.064 \\
\hline 84 & ROTI & 0.053 & 0.619 & 0.083 & 0.029 & 0.018 & 0.071 \\
\hline 85 & SAME & 0.053 & 0.441 & 0.083 & 0.029 & 0.013 & 0.066 \\
\hline 86 & ScCO & 0.053 & 0.926 & 0.083 & 0.029 & 0.027 & 0.081 \\
\hline 87 & SCMA & 0.053 & 1.704 & 0.083 & 0.029 & 0.050 & 0.103 \\
\hline 88 & SGRO & 0.053 & 0.250 & 0.083 & 0.029 & 0.007 & 0.061 \\
\hline 89 & SIDO & 0.053 & 0.250 & 0.083 & 0.029 & 0.007 & 0.061 \\
\hline 90 & SIMP & 0.053 & 1.144 & 0.083 & 0.029 & 0.034 & 0.087 \\
\hline
\end{tabular}




\begin{tabular}{|c|l|r|r|r|r|r|r|}
91 & SMBR & 0.053 & 4.080 & 0.083 & 0.029 & 0.120 & 0.173 \\
\hline 92 & SMGR & 0.053 & 1.993 & 0.083 & 0.029 & 0.059 & 0.112 \\
\hline 93 & SMRA & 0.053 & 2.229 & 0.083 & 0.029 & 0.066 & 0.119 \\
\hline 94 & SMSM & 0.053 & 0.608 & 0.083 & 0.029 & 0.018 & 0.071 \\
\hline 95 & SOCI & 0.053 & 1.579 & 0.083 & 0.029 & 0.047 & 0.100 \\
\hline 96 & TARA & 0.053 & -0.105 & 0.083 & 0.029 & -0.003 & 0.050 \\
\hline 97 & TBLA & 0.053 & 1.263 & 0.083 & 0.029 & 0.037 & 0.090 \\
\hline 98 & TELE & 0.053 & 1.464 & 0.083 & 0.029 & 0.043 & 0.096 \\
\hline 99 & TINS & 0.053 & 2.234 & 0.083 & 0.029 & 0.066 & 0.119 \\
\hline 100 & TLKM & 0.053 & 0.447 & 0.083 & 0.029 & 0.013 & 0.066 \\
\hline 101 & TOTL & 0.053 & 1.345 & 0.083 & 0.029 & 0.040 & 0.093 \\
\hline 102 & TSPC & 0.053 & 0.522 & 0.083 & 0.029 & 0.015 & 0.069 \\
\hline 103 & TURI & 0.053 & 0.337 & 0.083 & 0.029 & 0.010 & 0.063 \\
\hline 104 & ULTJ & 0.053 & -0.484 & 0.083 & 0.029 & -0.014 & 0.039 \\
\hline 105 & UNTR & 0.053 & 0.926 & 0.083 & 0.029 & 0.027 & 0.080 \\
\hline 106 & UNVR & 0.053 & 1.167 & 0.083 & 0.029 & 0.034 & 0.088 \\
\hline 107 & WIKA & 0.053 & 2.375 & 0.083 & 0.029 & 0.070 & 0.123 \\
\hline 108 & WSKT & 0.053 & 2.549 & 0.083 & 0.029 & 0.075 & 0.128 \\
\hline 109 & WTON & 0.053 & 1.368 & 0.083 & 0.029 & 0.040 & 0.094 \\
\hline
\end{tabular}

Sumber: Diolah

Lampiran 2

Tabel 5: Pengelompokan Saham Efisien dan Tidak Efisien

\begin{tabular}{|l|r|r|l|}
\hline \multicolumn{1}{|c|}{ Kode Perusahaan } & \multicolumn{1}{c|}{$\begin{array}{c}\text { Expected } \\
\text { Return/year }\end{array}$} & \multicolumn{1}{c|}{$\begin{array}{c}\text { Average } \\
\text { return/year }\end{array}$} & Efisien/Tidak Efisien \\
\hline AALI & 0.014915232 & 0.002707791 & tidak efisien \\
\hline ACST & 0.083694687 & -0.228704699 & tidak efisien \\
\hline ADHI & 0.122838711 & -0.166660013 & tidak efisien \\
\hline ADMF & 0.076677461 & 0.473647653 & efisien \\
\hline AKRA & 0.101936637 & -0.118429042 & tidak efisien \\
\hline ALMI & 0.075776358 & 0.175562736 & efisien \\
\hline AMRT & 0.041379857 & 0.105247484 & efisien \\
\hline APIC & 0.040329827 & 0.297428186 & efisien \\
\hline APLN & 0.102290165 & -0.13097623 & tidak efisien \\
\hline ARNA & 0.072138705 & -0.004234924 & tidak efisien \\
\hline ASGR & 0.060530924 & -0.084360725 & tidak efisien \\
\hline ASII & 0.092653024 & 0.044587211 & tidak efisien \\
\hline ASMI & 0.079554165 & 0.515789723 & efisien \\
\hline ASSA & 0.107846733 & 0.712651488 & efisien \\
\hline AUTO & 0.076904322 & -0.034405941 & tidak efisien \\
\hline BATA & 0.055641084 & -0.0406989 & tidak efisien \\
\hline BBCA & 0.084916921 & 0.287131051 & efisien \\
\hline BBKP & 0.119211635 & -0.209761194 & tidak efisien \\
\hline BBNI & 0.108298475 & 0.16771599 & efisien \\
\hline BBRI & 0.098023655 & 0.311379288 & efisien \\
\hline BBTN & 0.104155123 & 0.142005293 & efisien \\
\hline BBYB & 0.110383762 & 0.227951995 & efisien \\
\hline BDMN & 0.121856481 & 0.020201651 & tidak efisien \\
\hline BEST & 0.132248322 & -0.004925433 & tidak efisien \\
\hline & & & \\
\hline & & & \\
\hline & & &
\end{tabular}




\begin{tabular}{|c|c|c|c|}
\hline BJBR & 0.111596023 & 0.146102697 & efisien \\
\hline BMRI & 0.088988235 & 0.180832283 & efisien \\
\hline BMTR & 0.109556294 & -0.186775169 & tidak efisien \\
\hline BNBA & 0.074194107 & 0.199294039 & efisien \\
\hline BNGA & 0.128939203 & 0.141084744 & efisien \\
\hline BNLI & 0.111241212 & 0.216135592 & efisien \\
\hline BRNA & 0.0635577776 & 0.075495582 & efisien \\
\hline BRPT & 0.103817898 & 1.985312316 & efisien \\
\hline BSDE & 0.096397174 & -0.077381358 & tidak efisien \\
\hline BWPT & 0.108609342 & -0.024473202 & tidak efisien \\
\hline CLPI & 0.076791846 & 0.133826494 & efisien \\
\hline CMNP & 0.050387466 & 0.005967817 & tidak efisien \\
\hline CPIN & 0.079724759 & 0.204532704 & efisien \\
\hline CTRA & 0.092089769 & -0.041490416 & tidak efisien \\
\hline DLTA & 0.055503632 & 0.110330538 & efisien \\
\hline DNAR & 0.013031928 & 0.183194034 & efisien \\
\hline DNET & 0.05058823 & 0.294221265 & efisien \\
\hline DOID & 0.147419128 & 0.529556973 & efisien \\
\hline DSNG & 0.046733877 & 0.000160415 & tidak efisien \\
\hline DVLA & 0.053330273 & 0.20584711 & efisien \\
\hline ERAA & 0.105725394 & 0.416936702 & efisien \\
\hline EXCL & 0.056730952 & -0.035224021 & tidak efisien \\
\hline FASW & 0.050328997 & 0.718384546 & efisien \\
\hline GGRM & 0.089115998 & 0.012105264 & tidak efisien \\
\hline GIAA & 0.08486241 & 0.060946146 & tidak efisien \\
\hline HEXA & 0.018453265 & 0.612505613 & efisien \\
\hline HMSP & 0.137439509 & 0.060185571 & tidak efisien \\
\hline HRUM & 0.122355079 & 0.246682395 & efisien \\
\hline ICBP & 0.074455693 & 0.148673415 & efisien \\
\hline INAF & 0.132413495 & 0.370732997 & efisien \\
\hline $\mathrm{INCl}$ & 0.052889585 & 0.137996121 & efisien \\
\hline INCO & 0.098423707 & 0.266025943 & efisien \\
\hline INDF & 0.085840569 & 0.09822712 & efisien \\
\hline INTP & 0.106120457 & 0.028098596 & tidak efisien \\
\hline ISAT & 0.116565681 & -0.14176516 & tidak efisien \\
\hline ITMG & 0.133011827 & 0.387950914 & efisien \\
\hline JPFA & 0.104242698 & 0.258227694 & efisien \\
\hline JSMR & 0.0822814 & -0.01434581 & tidak efisien \\
\hline KBLI & 0.098894227 & 0.477318591 & efisien \\
\hline KLBF & 0.091823762 & 0.068599418 & tidak efisien \\
\hline KRAS & 0.0937412 & 0.006886857 & tidak efisien \\
\hline LPCK & 0.117436749 & -0.359439662 & tidak efisien \\
\hline LPPF & 0.100915123 & -0.253344918 & tidak efisien \\
\hline LSIP & 0.067901646 & 0.037939049 & tidak efisien \\
\hline MAIN & 0.107919046 & -0.052600166 & tidak efisien \\
\hline MCOR & 0.079140984 & -0.07086636 & tidak efisien \\
\hline MICE & 0.062065895 & 0.017549868 & tidak efisien \\
\hline MLBI & 0.047746484 & 0.243150783 & efisien \\
\hline MPMX & 0.055721043 & 0.219631156 & efisien \\
\hline
\end{tabular}




\begin{tabular}{|c|c|c|c|}
\hline $\mathrm{MYOH}$ & 0.078070341 & 0.472252464 & efisien \\
\hline MYOR & 0.055294294 & 0.254508879 & efisien \\
\hline PANS & 0.083311179 & -0.165892103 & tidak efisien \\
\hline PGAS & 0.107139587 & 0.001187981 & tidak efisien \\
\hline PNBN & 0.092507591 & 0.185739025 & efisien \\
\hline PNLF & 0.083231558 & 0.185658549 & efisien \\
\hline PTPP & 0.138494504 & -0.177720375 & tidak efisien \\
\hline PWON & 0.087075199 & 0.073186911 & tidak efisien \\
\hline RALS & 0.088875018 & 0.192238055 & efisien \\
\hline RANC & 0.063507091 & 0.030274253 & tidak efisien \\
\hline ROTI & 0.071465645 & -0.002124746 & tidak efisien \\
\hline SAME & 0.066222239 & -0.181065113 & tidak efisien \\
\hline SCCO & 0.080507855 & 0.321647165 & efisien \\
\hline SCMA & 0.103430453 & -0.130821695 & tidak efisien \\
\hline SGRO & 0.060587096 & 0.087785523 & efisien \\
\hline SIDO & 0.060587096 & 0.087785523 & efisien \\
\hline SIMP & 0.086924916 & 0.090605271 & efisien \\
\hline SMBR & 0.173402863 & 0.098081986 & tidak efisien \\
\hline SMGR & 0.111932398 & 0.048134954 & tidak efisien \\
\hline SMRA & 0.118881057 & -0.084855071 & tidak efisien \\
\hline SMSM & 0.071124542 & 0.159730583 & efisien \\
\hline $\mathrm{SOCl}$ & 0.099734164 & -0.212158603 & tidak efisien \\
\hline TARA & 0.050124051 & -0.083116412 & tidak efisien \\
\hline TBLA & 0.090443766 & 0.228357206 & efisien \\
\hline TELE & 0.096367324 & -0.183400071 & tidak efisien \\
\hline TINS & 0.119047245 & 0.141691737 & efisien \\
\hline TLKM & 0.066392536 & 0.065837989 & tidak efisien \\
\hline TOTL & 0.092856347 & -0.006643881 & tidak efisien \\
\hline TSPC & 0.068603212 & -0.032322632 & tidak efisien \\
\hline TURI & 0.063170418 & 0.066033171 & efisien \\
\hline ULTJ & 0.038985504 & 0.170767245 & efisien \\
\hline UNTR & 0.080494454 & 0.094206622 & efisien \\
\hline UNVR & 0.087613749 & 0.075970879 & tidak efisien \\
\hline WIKA & 0.123194715 & -0.051466524 & tidak efisien \\
\hline WSKT & 0.128323612 & -0.016692706 & tidak efisien \\
\hline WTON & 0.093529537 & -0.167362134 & tidak efisien \\
\hline
\end{tabular}

Sumber: Diolah 